\section{解説} Explanation

\title{
神戸大学大学院海事科学研究科 海事博物館*
}

\section{- 人・海・船の過去と現在, 夢ある未来が詰まった博物館}

\author{
野 村 昌 孝**
}

\section{1. 大学の沿革と博物館の概要}

平成 15 (2003)年 10 月に神戸商船大学が神戸大学と 統合して発足した神戸大学海事科学部は, 国際都市神 戸の一角，大阪湾を望む深江キャンパスにある．海事 科学部・大学院海事科学研究科では, 海事社会で活躍 できる専門的知識だけでなく, 基礎的な教育研究に重 点を置きながら総合大学の特色も活かした幅広い知識, 応用力, 開発能力を身につけるとともに, 国際的・学 際的・総合的な視野を持ち, 多様な学問を基礎とした 応用力をつけ，社会で通用する人材の育成を目指し， 船舶職員のみならず，海事行政官，研究者，各種メー カー, 銀行, 物流, 商社など多岐にわたる分野へ卒業 生を送り出している.

海事科学部の前身となる神戸商船大学は, わが国造 船界の先覚者である川崎正蔵氏の遺志を継いで大正 6 (1917)年 9 月に創設された私立川崎商船学校（設立者 川崎芳太郎氏）に始まる. 同校は大正 9 (1920)年 8 月 に国家に献納され，官立神戸高等商船学校に昇格後， 戦時措置により昭和 20 (1945)年 4 月, 東京・清水の 両高等商船学校とともに高等商船学校として統合され る一方, 校地・校舎を利用して海技専門学院（現在, 芦屋市にある独立行政法人海技教育機構海技大学校） が設置された. 昭和 27(1952)年 5 月, 神戸商船大学が 由緒ある深江の地に新制大学とし発足し, およそ半世

\begin{tabular}{|c|c|c|c|c|}
\hline & & & 神戸大学海事科学部 & 海事博物館 \\
\hline 大正 & 6(1917) & 年 9 月 & $\begin{array}{c}\text { (川崎正藏) } \\
\text { 私立川崎商船学校設立 } \\
\text { (川崎芳太郎) }\end{array}$ & \\
\hline & $9(1920)$ & 年 8 月 & 神戸高等商船学校設置 & 閏傒資料掇隻 (小閏三平) \\
\hline 昭和 & $20(1945)$ & 年 4 月 & $\begin{array}{c}\text { 高等商船学校 (清水) に統合 } \\
\text { (神戸分校, 海技専門学院設置) }\end{array}$ & \\
\hline 昭和 & $27(1952)$ & 年 & 神戸商船大学設立 $(5$ 月 $)$ & \\
\hline 昭和 & $33(1958)$ & & 実習船「深江丸」拨工 (3 月) & 海事参考館開館（11 月） \\
\hline 昭和 & $35(1960)$ & 年 7 月 & & 第 1 回海事調査団派遣 \\
\hline 昭和 & $37(1962)$ & 年 3 月 & & 別館 1 階改造・移転 \\
\hline 昭和 & $42(1967)$ & 年 9 月 & & 海事資料館講堂䇋工 \\
\hline 昭和 & $43(1968)$ & 年 7 月 & & 「海事資料館」へ改称 \\
\hline 平成 & $7(1995)$ & 年 1 月 & 䦻神淡口文 & 震災 \\
\hline 平成 & $15(2003)$ & 年 10 月 & 大学統合 & \\
\hline 平成 & $16(2004)$ & 年 10 月 & & \\
\hline 平成 & $25(2013)$ & 年 3 月 & & 海事博物館 \\
\hline 平成 & $29(2017)$ & 年 & 創基 100 周年 & 歴史資料等 \\
\hline
\end{tabular}

図 1 神戸大学海事科学部, 海事科学博物館沿革

*原稿受付 平成 29 年 10 月 20 日。

**正会員 神戸大学 (神戸市東灘区深江南町 5-1-1).
紀の歳月を経て現在の神戸大学海事科学部誕生に至る. 海事博物館は, 海事思想普及のため海事博物館を必 要と考えた小関三平神戸高等商船学校第二代校長 （1923～1935)による関係資料収集に始まる. 文書類お よそ 200 点のほか模型等多数を集めたが，目録が作ら れないまま昭和 20 (1945)年 5 月 11 日，8月 7 日の空 襲によってほとんどが消失した．これらの海事資料は 当時としても珍しかったらしく, 新聞に紹介されたり しているほか，神戸市が昭和 5 (1930)年 9 月に行われ た観艦式を記念して海港博覧会を開催した際にも出品 展示がなされている. 神戸商船大学設立から 6 年後, 学生食堂として使用していた木造建物の一室を改造し て, 昭和 33 (1958)年 11 月に学内に分散していた資料 を集めて海事参考館が開設された. 開館当時の資料は, 戦災を免れた私立川崎商船学校創立と同時に教材用と して寄贈された模型類, 戦後関係者が各方面から収集 した教材類の一部，開設にあたり卒業生その他から寄 贈を受けた学校沿革資料などであった. その後も引き 続いて, 教材, 参考品として購入製作された航海計器, 各種機関の実物などとともに陳列されて学生の教育参 考に供されていた，その後，昭和 33 (1958)年に完成 した 150 トンの小型練習船「深江丸」を利用し, 瀬戸 内海周辺の資料の調查収集と海事思想の普及を意図し て海事調査が昭和 35 (1960)年夏に始まった。 昭和 36 (1961)年には，名称を神戸商船大学海事資料館と改称 した．昭和 48 (1973)年からの 10 年間, 文部省から配 分された予算により年報を発刊するとともに江戸時代 の航路図など の購入を行った. 平成 7 (1995)年 1 月

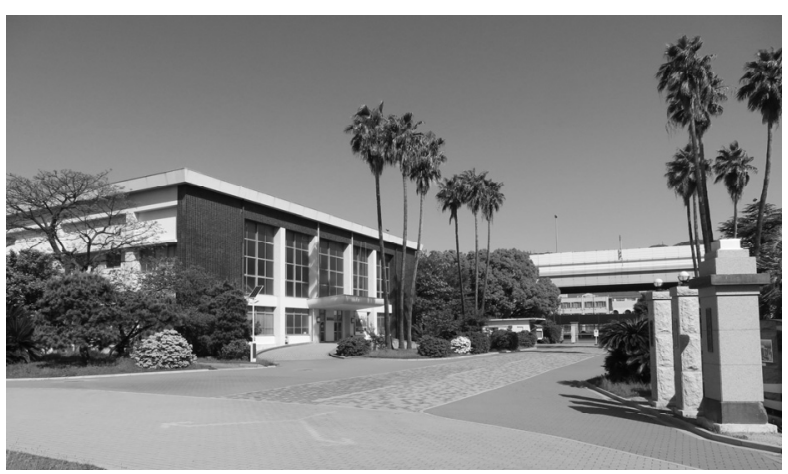

図 2 神戸大学海事科学博物館 
の大地震は，展示物はもとより倉庫に保管していた資 料にも大きな被害を与えた。復旧予算が付いた一部の 重要展示物以外は倉庫内に散乱していたが，神戸大学 との統合前に神戸商船大学 $\mathrm{OB}$ 有志が散乱した資料の 整理に乗り出し，念願であった資料の本格的な整理事 業が始められた。神戸大学との統合より 1 年後の平成 16 (2004)年 10 月に現在の神戸大学大学院海事科学研 究科海事博物館と改称したが，この間展示館も場所を 変え, 現在は昭和 $42(1967)$ 年に完成した講堂の一階 を展示室などとして利用している.

平成 25 (2013)年 4 月には内閣府の歴史資料等保有 施設の指定を受け, 平成 29(2017)年に「近畿地方整備 局長表彰」を受賞するなど，海事思想の普及および海 事教育への貢献が認められている. 現在, 週 3 日の午 後だけではあるが開館することになり, OB が交代で 勤務し, 事務担当のパートタイマーと協力して来館者 の案内, 解説, 資料の整理などの運営にあたっている.

\section{2. 主な所蔵資料}

本博物館の所蔵品は, 広く海事に関寸るもの一般に わたっているが, 開設当初以来資料収集に努力した教 員が特に和船関係に造詣が深かったため, 自然その方 面の所蔵品が充実している. また, 戦後の高度成長に よる資料の消滅を防ぐことも目的として実施された海 事調査により集められた資料も多い: ニニークな収蔵 品としては, 明治初年の和船板図 (設計図), 大小 20 点あまりの和船模型，それに関連して和船の一部や部 品資料がある.

ほかに，航海の安全を祈願し神社仏閣に奉納した船 絵馬, 船頭たちが手回り品を入れた船箪笥, 和磁石, 船具類, 船鑑札や船大工道具も少数ながら所蔵されて いる. また, 江戸時代の航路図や航海書など, その種 類, 数も多量で, 貴重な資料も数々あり, 全国第一の 充実ぶりといってよい.

これらの内，いくつかの資料がバーチャルミュージ アムとして電子化され博物館 Web ページで公開され ている. 現在, バーチャルミュージアムには, 航海図・ 海路絵図巻として, 『海路図屏風下絵』, 『海路図屏風六 曲一双』, 『江戸より長崎道中図巻』, 『開成丸航路図』, 『浪速至東都図解』, 『海路絵図巻』, 電子船舶模型とし て『北前船「天昭丸」』.『油槽船「Stanvac Japan」』, 海事関連古文書として『造船大工見積秘伝書』が電子 データならではの機能で細部に至る点まで閲覧・確認 できる.

\section{1 天昭丸（和船模型）}

神戸高等商船学校時代からの数少ない模型の一つで あり, 模型内部に昭和 5 年 10 月大阪天野造船所天野
三吉作と記されている (図 3). 模型とともに和船に関 する寸法書も寄贈されたと言われるが，戦災時の全焼 によって失われたものか, 残念ながら現存しない. 天 野三吉氏は大阪の造船所主であって, 若い頃北前船の 建造に従事し，老年になってから記念のため模型を製 作寄贈したという。

本模型は全長 $1.06 \mathrm{~m}$ の小型のものではあるが, 精巧 を極め, 使用材料は実際の和船と同様の材質を選び, 構造等は細部にいたるまで省略寸ることなく, 細かく 彫刻をほどこし, 船内艤装品も完備した一品である. 製作には 5 年の日時を要したと言われるのももつとも であろう．船形もアカマ梁で最も幅が広く, 䑶装も明 治中期の北前船末期の特徵をよく示し, 各部寸法の比 率も正確であって，北前船の標淮的な模型ということ ができる.

かつて展覧会に出品した際，一老人が長時間熱心に 眺めた末，綱の結び方一つにいたるまで入念かつ正確 に作ってあることに感嘆したとの談が残っている.

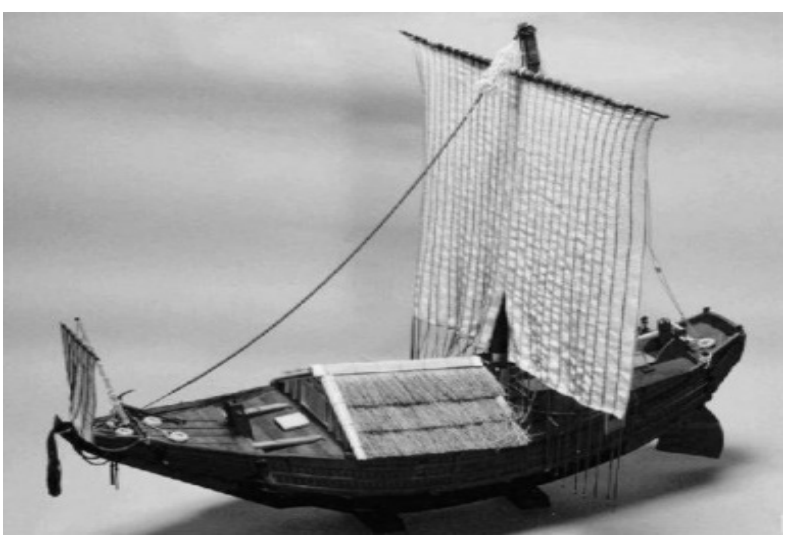

図 3 天昭丸

\section{2 遠眼鏡}

ヨーロッパ人は日本に種々の器物をもたらしたが, 遠眼鏡もその一つであった，その後，これを模して長 崎でも製作されるようになり，続いて各地に制作者が 現れた，日本製の望遠鏡は，筒を竹，あるいは一貫張 りとし，筒表面には美しく金で模様を描いた漆塗りの ものが多い. もちろん相当な価格であったから, 通常

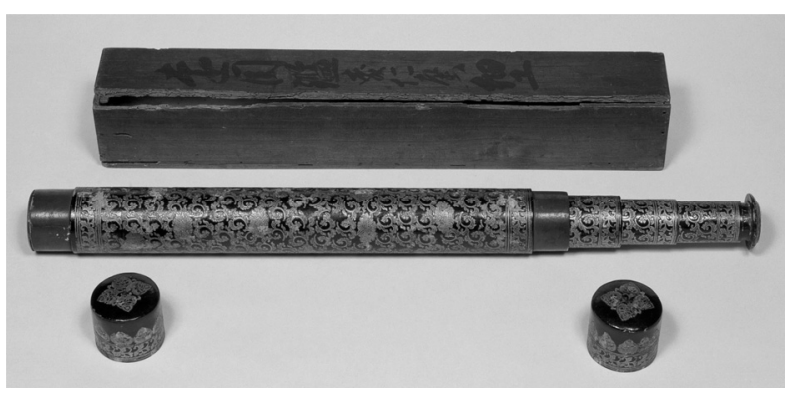

困 4 遠眼鏡 
の船頭が所持できる道具ではなかった。

図 4 の遠眼鏡は, 木箱蓋表に遠目鑑森仁左衛門細工， 蓋裏に浪速原所持と墨書されている. 森仁左衛門は享 保年間 $(1716 〜 35)$, 長崎で望遠鏡を作ったといわれ, 日本における望遠鏡製作者としては最も初期の人物で ある. 全長 $1.3 \mathrm{~m}$.

\section{3 船箪笉}

和船船頭たちは手廻り品を納めるため，船箪笥を持 って乗船していた. 船箪笥の中でも最も数の多いのは, 懸硯とよばれる金銭書類等を入れるためのもので，こ のほかにも衣類を入れる半櫃等があった。

図 5 は懸硯であって，懸硯は重要書類を入れる手提 金庫のようなものであるから，入港して船頭が船宿に 宿泊する際には持参して上陸しなければならなかった。 通常, 内部は桐，外側は欅で頑丈に作られ，隅々およ び前面には多数の金具を取り付けている．特に前面の 金具は装飾を兼ねている. 本学所蔵のものは大部分既 製品として販売されていたと思われる船箪笥で, 美術 的に優れたものではない. しかし旧船主から寄贈され たものが多く，実際に使用された跡を残している.

図の懸硯は，所持していた船頭が蓋裏に当時の美人 版画を貼り付けており，かつての和船船頭の生活の一 端をしのばせている.

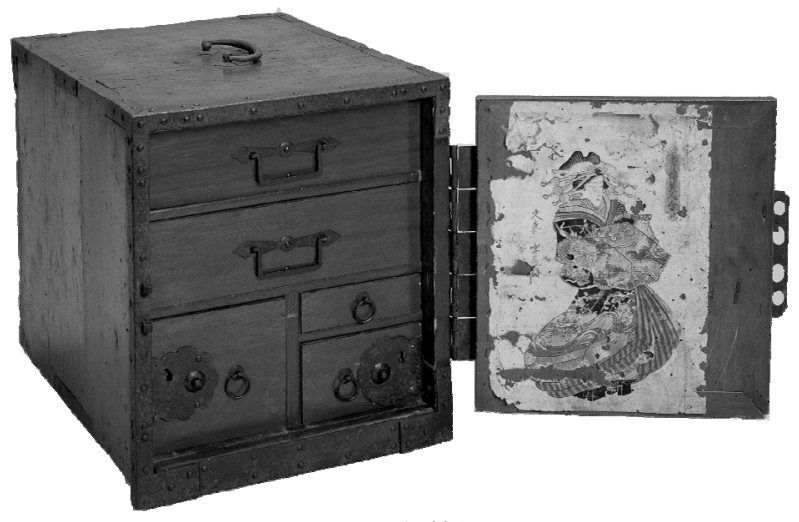

図 5 船篂笥

\section{4 海路図屏風}

江戸時代の航路図には船頭たちが実用に供した質素 なもののほかに, 装飾的なものが数多く残っているが, 図 6 の屏風はその中でも最も豪華なものに属する.も ちろん図中には島をぬって朱線で航路を記入して航路 図の形態をとってはいるが，実際の航海に使用するも のではない. 西国大名の参勤交代の御座船では, 船屏 風といわれている高さの低い屏風を船の動摇によって 倒れないよう吊り下げて使用したが，本品にはそのよ うな吊り金具はなく，おそらく陸上で使用したものと 思われる．本屏風は大阪から長崎に至る瀬戸内海の海
路を六曲一双に描き，岩国附近を境に東西を分かって いる. 図は主な島，町，城などを細かく記入するとと もに，彩色をほどこした豪華なものであり，保存は良 好である．筆者，製作年代の記入はないが，記入され ている文字などから，元禄時代以前の製作と推定され る.もつとも，地図そのものは江戸初期のものに基づ いて画かれている.
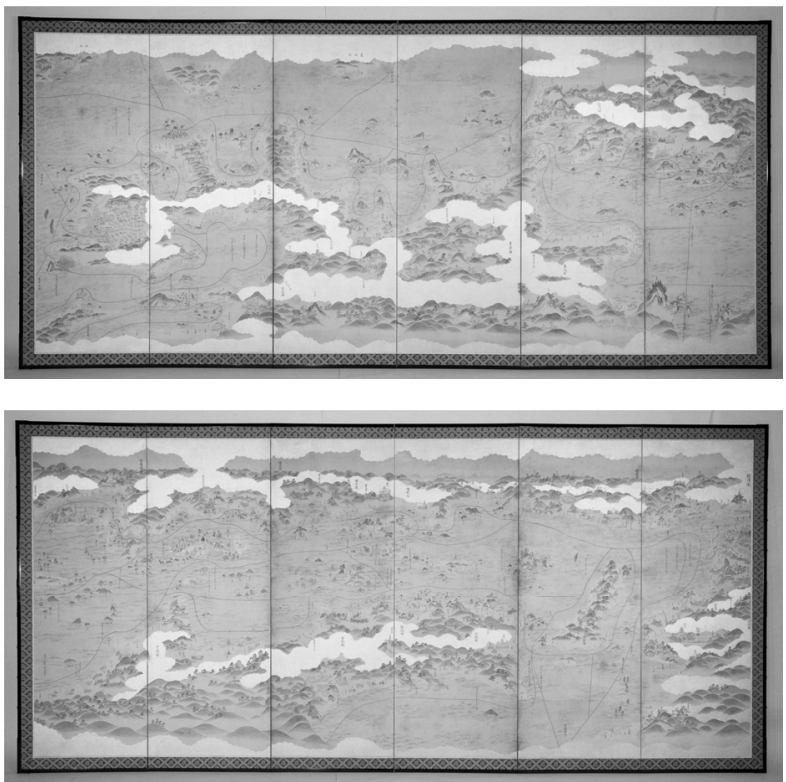

図 6 海路図屏風

これらのほかに，戦前からの旅客船関係資料を集め たユニークな「仲島忠治郎コレクション」が昭和 55 (1980)年頃に寄贈された，学生，OB らの長年の努力 により, 撮影, 整理され, 海運・造船会社等の案内・ 報告書類, 携帯用の時刻表, デッキプラン・キャビン プラン，進水絵葉書，ポスターなど貴重で珍しい海外 資料，国内資料を含めて 14,000 点近いコレクション となっている. さらに, 戦前・戦中の日本商船全船を 網羅する約 4,600 隻の「日本の商船隊行動記録集」な らびに 102 隻に及ぶ $1 / 600$ 精密船舶模型などから構成 される船舶資料集「山田早苗コレクション」（図 7) が
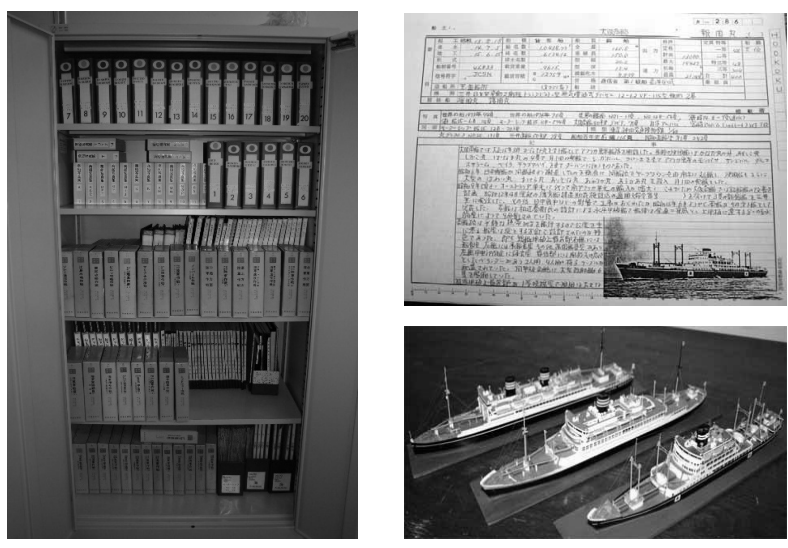

図 7 山田早苗コレクション 
平成 16 (2004)年 10 月に寄贈されるなど，和船以外の 資料も多くなっている.

現在の所蔵品数は，二万数千点の歴史実物資料を有 し, その内, 模型類約 400 点, 写真類約 5,000 点, 他 に書籍文書類多数あり, 一般の人々の縌覧に供してい る. 全国多数の大学のうちにも，これだけの海事関係 資料の夕を所蔵・展示寸る大学は少なく, ユニークな 博物館として関係者からの注目も高く, 本学にとって も誇るべき施設であると言えよう。

\section{3. 博物館の活動・事業}

所蔵資料は, 学生の教育活動に常時利用されており, 地域小中学生の希望, 高校生の模擬講義や施設見学な どのキャンパス訪問, 学内諸行事開催の際には見学会 を実施している，活動としては，常設展示，企画展， 市民セミナー (公開講座) を行っている. 所蔵する豊 富な資料から, 江戸末期の北前船模型類, 和船関係, 航海計器類など約 260 点が「常設展示」されており, 企画展開催の際に併せて資料の展示換えを行っている.

平成 17 (2005)年の海の日から始まった「企画展」 も毎年開催しており, 今年で 13 回を数える. 毎回テ 一マを決め, 今まで公開される機会のなかった博物館 所蔵資料の展示とともに他の博物館, 関連企業からも 資料を借りて毎年 7 月の海の日前後から 10 月末まで の期間で実施している. 企画展のテーマに関連してさ らなる詳細な内容を学内外の講師を招いて講義を行う 「市民セミナー (公開講座)」も 10 月から 12 月の土 曜日に数回にわたり実施している. 平成 7 (1995)年の 震災の折には，被害を受けた資料等の修復過程で，資 料の永久保存方法としてデジタルカメラを使った画像 によるデータベース化とともに全国に散在している海 事資料とのリンクを目的としたアーカイブ化を積極的 に進めてきた. 現在では, 相当数の資料が電子情報と して登録され，博物館 Web ページで公開するととも に 3,000 点あまりの資料がデータベース化・検索可能

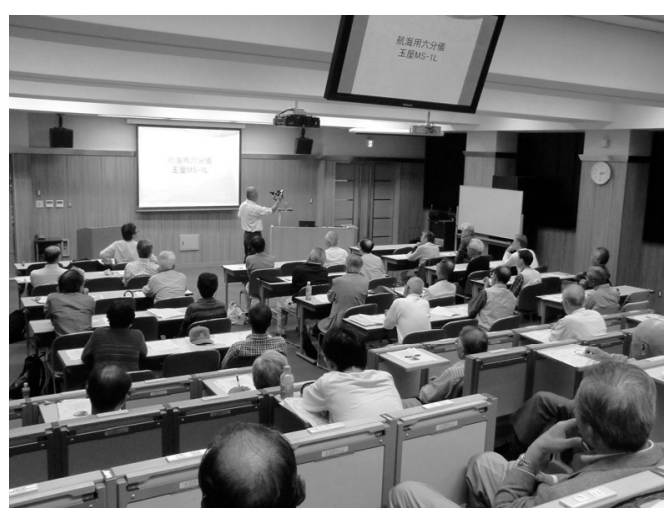

図 8 市民セミナー (公開講座) 風景
となっており，外部からの資料貸し出しに際してもよ く利用されている.

学芸員など専門の常駐スタッフが配置できないなか, 本博物館の現状は，資料の収集・整理・保存からよう やく社会に公開できる段階についたところである．今 後は, さらなる活動の充実と大学が有する博物館とし て社会に対して海事関連の研究調查が可能な「研究セ ンター」としての役割も視野に入れるとともに，広く 海事に関心を持つ人たちの集える「夢溢れる」博物館 の実現を目指している.

\section{神戸大学海事博物館}

http://www.museum.maritime.kobe-u.ac.jp/

開館日：月・水・金 $\cdots \cdots \cdot 13: 30 \sim 16: 00$

休館日：火・木・土・日・祝祭日・お盆・年末年始 その他大学の定めた休館日

\section{見学のお問合せ ·連絡先}

Tel : 078-431-3564（不在の場合は 078-431-6200）

E-mail : siryokan@maritime.kobe-u.ac.jp 学校，団体などの見学は事前にご連絡ください

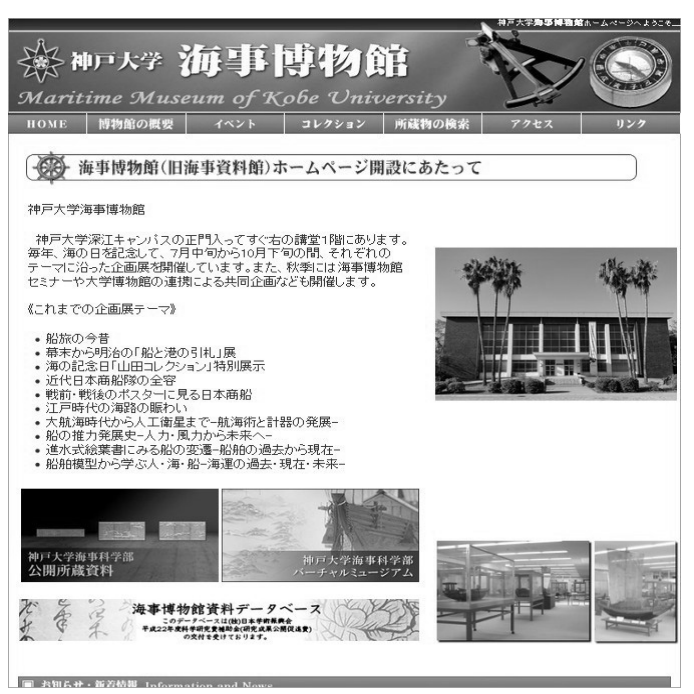

図 9 神戸大学海事博物館 Web ページ

著者紹介

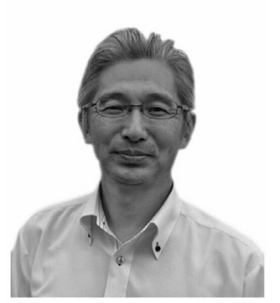

姓 名 野村 昌孝

・日本マリンエンジニアリング学 会 正会員

· 1965 年生.

- 神戸大学大学院海事科学研究科.

. 大阪大学大学院. 博士 (工学).

·材料加工学, 材料力学. 